(C) 2018

\author{
Штугеревич В. С., здобувач
}

Полтавська державна аграрна академія

\title{
ЕФЕКТИВНІСТЬ ПОЗАКОРЕНЕВОГО ЗАСТОСУВАННЯ СТИМУЛЯТОРА РОСТУ «4R FOLIAR CONCENTRATE» НА ПOCIBAX ЯЧМЕНЮ ЯРОГО
}

\author{
Рецензент - доктор сільськогосподарських наук, професор М. Я. Шевніков
}

У досліді, який проводили у виробничих умовах, були отримані результати, які свідчать про досить високу ефективність застосування препаратів, створених на основі гумінових речовин. Позакореневе використання преnapamy «4R Foliar concentrate» (США) в нормі 1,5-2 кг/га дало змогу істотно збільшити врожайність зерна ячменю. В середньому за три роки досліджень обприскування посівів сприяло зростанню врожайності на 11,4-22,8\% за норми висіву 4,5 млн ит. насінин/حа. В разі зменшення норми до 4 млн шт. урожайність контрольного варіанmу (без обприскування) становила дещз меншу величину, проте динаміка ї̈ зростання в оброблених посівах була значно кращою - підвищення рівня врожайності становило 30,4\%.

Обробка посівів препаратом «4R Foliar concentrate» сприяла збільшенню маси 1000 зерен на 1,1-4,2 г залежно від норми висіву, а крупність зерна зросла на $6-8 \%$.

Норми висіву насіння, які передбачають у середньому 4,5 млн ит./га, можуть бути недоиільними, оскільки різниця між контрольними варіантами за врожайністю є неістотною, але зменшення їх на 0,51 млн є иілком економічно виправданим. Так, у разі зменшення норм висіву насіння на 1 млн ит./га врожайність змінюється несуттєво, але рентабельність виробництвва зростає майже на $10 \%$. Навіть у разі великих норм висіву рентабельність виробництва зростає на 9-24\%.

Ключові слова: ячмінь ярий, норми висіву, урожайність, якість зерна, економічна ефективність.

Постановка проблеми. Удосконалення технології вирощування ячменю ярого - надзвичайно актуальне завдання, оскільки в нинішніх економічних умовах здешевлення виробництва зерна та підвищення його рентабельності можливе лише в разі впровадження нових агротехнічних прийомів, які не передбачають таких великих затрат як, наприклад, добрива або насіння. У зв'язку з цим оптимізація норм висіву та підвищення ефективності використання поживних речовин за допомогою стимуляторів росту має істотні перспективи для широкого впровадження.

Аналіз останніх досліджень та публікацій, у яких започатковано розв'язання проблеми.
Ячмінь відноситься до культур, які значною мірою формують продуктивність за рахунок ефективної кущистості, тому питання встановлення оптимальних норм висіву насіння є актуальним. Існує твердження, що використання великих норм висіву (4,5-5 млн шт. насінин на 1 га) $\epsilon$ економічно недоцільним і лише низький рівень агротехніки це виправдовує.

Одним 3 ефективних способів підвищення врожайності та зменшення норм висіву часто називають застосування стимуляторів росту, створених на основі солей гумінових кислот. У закордонних і вітчизняних публікаціях наводяться позитивні результати використання таких препаратів для передпосівної обробки насіння, позакореневого застосування та внесення в грунт. Ця тематика досить детально розглядається в роботах науковців Науково-дослідного Інституту агрохімії та грунтознавства імені О. Н. Соколовського, Львівського Національного аграрного університету, Полтавської державної аграрної академії, Полтавської сільськогосподарської дослідної станції імені М. І. Вавилова та ін.

Останні дослідження українських вчених досить детально розглядають проблематику оптимізації живлення сільськогосподарських культур. Для ячменю ярого ефективними нормами застосування добрив $\epsilon \mathrm{N}_{60} \mathrm{P}_{60} \mathrm{~K}_{80}$, а збільшення їх до $\mathrm{N}_{90} \mathrm{P}_{90} \mathrm{~K}_{120}$ може призвести до вилягання посівів $\mathrm{i}$, таким чином, до зменшення врожайності $[6,7]$.

Збільшенню врожайності 3 великою ймовірністю можуть сприяти ресурсозберігаючі біологічні технології, які розглядають елементи технології вирощування (строки сівби і норми висіву, удобрення, пестициди, біопрепарати) взаємозв'язку: грунт - погода - рослина - сорт - добрива - пестициди - довкілля [3]. В умовах недостатнього чи нестійкого зволоження такий підхід може виявитися ще ефективнішим - зростання врожайності зернових може становити 10-15\% $[8,9]$.

Незбалансоване застосування хімічних засобів вирощування рослин призводить до порушення екологічного балансу, скорочення кількості грунтової біоти, значного забруднення грунтів та сте- 


\section{СІЛЬСЬКЕ ГОСПОДАРСТВО. РОСЛИННИЦТВО}

рилізації гумусу. Крім того знижується якість продуктів харчування, що прямо загрожує виживанню людства $[2,4]$. Тому все актуальнішими стає біологізація технологій вирощування, в яких використовуються препарати захисту, підживлення рослин, створені на основі природної сировини. Одними з таких препаратів є група речовин, які мають гумінову природу та використовуються для обробки насіння [1].

Метою досліджень було визначення особливостей впливу стимулятора росту «4R Foliar concentrate» на врожайність ячменю, оптимізація норм висіву насіння та оцінка економічної ефективності застосування нових гумінових препаратів у посівах.

Матеріал і методика проведення досліджень. Дослід передбачав вивчення технологічних прийомів вирощування, які можуть забезпечити реалізацію генетичного потенціалу сортів ячменю, отримання максимального економічного ефекту технології вирощування без застосування мінеральних та комбінованих добрив i скорочення витрат засобів захисту рослин.

Сівбу проводили рядковим способом сівалкою «Horsch Pronto 6 AS» після попередника кукурудза на зерно, розміщення варіантів у досліді рандомізоване [5]. Для досліду було обрано сорт ячменю Джерзей, норма висіву насіння якого рекомендована оригінатором у межах 3,5-4,5 млн насінин на 1 гектар. Схема досліду передбачала вивчення норм висіву - фактор А $(4,5 ; 4,0$ та 3,5 млн шт/га, відповідно $\mathrm{a}_{1}, \mathrm{a}_{2}, \mathrm{a}_{3}$ ) та застосування стимулятора росту - комплексного гумінового препарату «4R Foliar concentrate» - фактор В: без препарату - $b_{0}, 1,5$ кг/га - $b_{1}, 2$ кг/га $\mathrm{b}_{2}$ i 2 кг/га у два прийоми $-\mathrm{b}_{3}$. Облікова площа ділянки - 0,324 га.
1. Контроль (прийнята в господарстві технологія 3 нормою висіву 4,5 млн шт./га $\left(\mathrm{a}_{1} \mathrm{~b}_{0}\right)$.

2. Норма висіву 4,5 млн шт/га та застосування «4R Foliar concentrate» 1,5 кг/га у фазі кущення за внесення розчину 200 л/га $\left(\mathrm{a}_{1} \mathrm{~b}_{1}\right)$.

3. Норма висіву 4 млн шт/га та застосування «4R Foliar concentrate» 2 кг/га у фазі кущення за внесення розчину 270 л/га.

4. Норма висіву 3,5 млн шт/га та застосування «4R Foliar concentrate» 1 кг/га у фазі кущення за внесення розчину 135 л/га та ще одного внесення такої ж кількості препарату у фазу виходу в трубку.

Статистичну обробку результатів експерименту проводили методами дисперсійного і кореляційного аналізів, використовуючи програму STATISTICA 10.0 .

Результати досліджень. У досліді, який проводили у виробничих умовах, було отримано результати, які свідчать про досить високу ефективність застосування препаратів, створених на основі гумінових речовин, та значну перспективу в напрямі реалізації генетичного потенціалу сортів ячменю. Зокрема, позакореневе використання препарату «4R Foliar concentrate» (США) в нормі 1,5-2 кг/га дало змогу істотно збільшити врожайність зерна ячменю (табл. 1).

У середньому за три роки досліджень обприскування посівів сприяло росту врожайності на $11,4-22,8 \%$ за норми висіву 4,5 млн шт. насінин/га. У разі зменшення норми на 0,5 млн шт. урожайність контрольного варіанту без обприскування становила дещо меншу величину, проте динаміка її зростання в оброблених посівах була значно кращою - підвищення рівня врожайності становило $30,4 \%$.

\section{1. Урожайність ячменю, ц/га (2015-2017 рр.)}

\begin{tabular}{|c|c|c|c|c|c|}
\hline \multirow{2}{*}{ Норма висіву $(A)$} & \multirow{2}{*}{ Варіант обробки $(B)$} & \multicolumn{3}{|c|}{ Роки } & \multirow{2}{*}{ Середня } \\
\hline & & 2015 & 2016 & 2017 & \\
\hline \multirow{4}{*}{ 4,5 млн шт./га } & без обприскування & 33,5 & 47,1 & 27,4 & 36,0 \\
\hline & 1,5 кг/га «4R Foliar concentrate» & 35,7 & 51,4 & 33,2 & 40,1 \\
\hline & 2 кг/га «4R Foliar concentrate» & 42,0 & 53,3 & 34,2 & 43,2 \\
\hline & $1 \kappa г / г \mathrm{a}+1 \kappa г / г \mathrm{a}$ «4R Foliar concentrate» & 39,9 & 57,3 & 35,3 & 44,2 \\
\hline \multirow{4}{*}{4 млн шт./га } & без обприскування & 32,9 & 46,0 & 26,3 & 35,1 \\
\hline & 1,5 кг/га «4R Foliar concentrate» & 38,9 & 51,0 & 29,7 & 39,9 \\
\hline & 2 кг/га «4R Foliar concentrate» & 41,4 & 55,4 & 33,0 & 43,2 \\
\hline & 1 кг/га +1 кг/га «4R Foliar concentrate» & 42,6 & 58,2 & 36,5 & 45,8 \\
\hline \multirow{4}{*}{ 3,5 млн шт./га } & без обприскування & 33,2 & 46,2 & 26,8 & 35,4 \\
\hline & 1,5 кг/га «4R Foliar concentrate» & 38,8 & 50,5 & 32,1 & 40,5 \\
\hline & 2 кг/га «4R Foliar concentrate» & 43,3 & 54,0 & 33,0 & 43,4 \\
\hline & 1 кг/га + 1 кг/га «4R Foliar concentrate» & 45,0 & 59,1 & 33,1 & 45,7 \\
\hline
\end{tabular}


Дія стимулятора та способу його застосування мала певні особливості за роками досліджень. Найоптимальнішими для посівів ячменю були умови 2016 року, коли на початку вегетації випали рясні дощі, а невисокі температури не спричинили негативної дії, внаслідок чого урожайність зерна досягала п’яти тон 31 га і більше. $\mathrm{У}$ цей рік основним фактором підвищення врожайності була саме обробка посівів гуматом. Рослини й без впливу норм висіву формували досить вагомий врожай, оскільки мали достатню кількість вологи для кущіння та формування продуктивного стеблостою.

У 2015 і 2017 роках, які були дещо гіршими за умовами, в порівнянні з 2016-м, частка впливу обробки посівів на врожайність була також найбільшою, хоча вплив норми висіву був також істотним. HIP $_{05}$ у 2015 році становила 3,18 ц/га та 2,52 і 2,47 ц/га у наступні роки.

Дані таблиці свідчать про те, що врожайність ячменю залежить від факторів вирощування значно більше, ніж від норм висіву, а застосування сучасних високоефективних $\mathrm{i}$ якісних стимуляторів гумінового походження дає змогу значно оптимізувати процеси формування продуктивності й отримати стабільні прибавки врожайності. Оскільки застосування гуматів оптимізує процеси живлення рослин, то можлива й їхня дія на показники якості зерна ячменю, особливо ті, що $\epsilon$ найважливішими для пивоварних якостей. Можливо передбачити, що зменшення норми висіву насіння призведе до формування краще виповненого зерна, яке матиме більшу масу 1000 зерен та крупність. Як свідчать результати аналізу деяких показників якості зерна, обробка посівів препаратом «4R Foliar concentrate» сприяла збільшенню маси 1000 зерен на 1,1-4,2 г залежно від норми висіву, а крупність зерна зросла на 6-8 \% (табл. 2).

Вплив норм висіву та застосування «4R Foliar concentrate» на вміст білка в зерні ячменю був неістотним. Враховуючи кореляції показників якості зерна між собою, можна спрогнозувати, що він буде таким самим і на решту показників якості, які формують його придатність до пивоваріння.

Таким чином, застосування препаратів гумінової природи має істотний позитивний вплив на формування врожайності ячменю ярого, сприяє поліпшенню фізичних показників якості зерна та має серйозні перспективи для широкого впровадження у виробництво. Використання гуматів дає змогу сортам ячменю краще реалізовувати їхній генетичний потенціал та значно стабілізувати показники врожайності за несприятливих умов вирощування.

Як свідчать показники економічної ефективності, норми висіву насіння, які передбачають у середньому 4,5 млн шт./га, можуть бути недоцільними, оскільки різниця між контрольними варіантами за врожайністю $\epsilon$ неістотною, але в грошовому еквіваленті зменшення їх на 0,5-1 млн $\epsilon$ цілком економічно виправданим. Навіть таким способом можливо підвищити економічну ефективність вирощування ячменю. Так, у разі зменшення норм висіву насіння на 1 млн шт./га врожайність змінюється несуттєво, але рентабельність виробництва зростає майже на $10 \%$ (табл. 3).

Використання гуматів для позакореневого застосування може значно оптимізувати технологію вирощування й підвищити рівень економічної ефективності. Навіть у разі великих норм висіву рентабельність виробництва зростає на 9$24 \%$, зростають також й інші економічні показники: чистий дохід, для прикладу, збільшується на 1563-3476 грн/га.

\section{2. Показники якості зерна ячменю (2015-2017 рр.)}

\begin{tabular}{|c|l|c|c|c|}
\hline $\begin{array}{c}\text { Норма } \\
\text { висіву } A\end{array}$ & \multicolumn{1}{|c|}{ Варіант обробки $B$} & $\begin{array}{c}\text { Маса } 1000 \\
\text { зерен, } \Gamma\end{array}$ & $\begin{array}{c}\text { Крупність, } \\
\%\end{array}$ & $\begin{array}{c}\text { Вміст білка, } \\
\%\end{array}$ \\
\hline \multirow{3}{*}{4,5 млн } & без оприскування & 40,67 & 82 & 11,53 \\
шт./га & 1,5 кг/га «4R Foliar concentrate» & 42,67 & 85 & 11,47 \\
& 2 кг/га «4R Foliar concentrate» & 44,63 & 87 & 11,57 \\
& 1 кг/га + 1 кг/га «4R Foliar concentrate» & 44,70 & 90 & 11,63 \\
\hline \multirow{3}{*}{4 млн } & без оприскування & 41,63 & 82 & 12,07 \\
шт./га & 1,5 кг/га «4R Foliar concentrate» & 42,73 & 86 & 11,63 \\
& 2 кг/га «4R Foliar concentrate» & 44,03 & 88 & 11,70 \\
& 1 кг/га + 1 кг/га «4R Foliar concentrate» & 44,57 & 90 & 11,67 \\
3,5 млн & без оприскування & 41,93 & 83 & 12,03 \\
шт./га & 1,5 кг/га «4R Foliar concentrate» & 44,07 & 87 & 11,73 \\
& 2 кг/га «4R Foliar concentrate» & 44,87 & 90 & 11,93 \\
& 1 кг/га + 1 кг/га «4R Foliar concentrate» & 46,13 & 89 & 11,77 \\
\hline
\end{tabular}


СІЛЬСЬКЕ ГОСПОДАРСТВО. РОСЛИННИЦТВО

3. Економічна ефективність позакореневого застосування стимулятора росту "4R Foliar concentrate» залежсно від норм висіву насіння (в цінах 2017 року)

\begin{tabular}{|c|l|c|c|c|}
\hline $\begin{array}{c}\text { Норма } \\
\text { висіву }(A), \\
\text { млн шт./га }\end{array}$ & \multicolumn{1}{|c|}{ Варіант обробки $(B)$} & $\begin{array}{c}\text { Собівартість } \\
1 \text { ц, грн }\end{array}$ & $\begin{array}{c}\text { Чистий } \\
\text { дохід, грн }\end{array}$ & $\begin{array}{c}\text { Рентабель- } \\
\text { ність, \% }\end{array}$ \\
\hline \multirow{3}{*}{4,5} & без оприскування & 298 & 8701 & 81 \\
& 1,5 кг/га «4R Foliar concentrate» & 284 & 10264 & 90 \\
& 2 кг/га «4R Foliar concentrate» & 270 & 11668 & 100,1 \\
& 1 кг/га + 1 кг/га «4R Foliar concentrate» & 265 & 12177 & 104,2 \\
\hline \multirow{3}{*}{4} & без оприскування & 296 & 8657 & 82,5 \\
& 1,5 кг/га «4R Foliar concentrate» & 277 & 10487 & 94,8 \\
& 2 кг/га «4R Foliar concentrate» & 262 & 11992 & 105,8 \\
& 1 кг/га + 1 кг/га «4R Foliar concentrate» & 250 & 13316 & 116,6 \\
\hline \multirow{3}{*}{3,5} & без оприскування & 282 & 9196 & 91,2 \\
& 1,5 кг/га «4R Foliar concentrate» & 265 & 11116 & 103,4 \\
& 2 кг/га «4R Foliar concentrate» & 254 & 12418 & 112,7 \\
& 1 кг/га + 1 кг/га «4R Foliar concentrate» & 243 & 13589 & 122,6 \\
\hline
\end{tabular}

Зменшення норм висіву до 4 млн шт./га та застосування «4R Foliar concentrate» дає змогу збільшити рівень рентабельності на 12,3-34,1\%. Якщо ж використовувати норми висіву 3,5 млн шт./га, то в середині блоку досліду зростання рентабельності становитиме 8,2-31,4\%, але порівняно 3 найбільшими нормами ці показники будуть значно вищими.

Результати економічної ефективності вирощування ячменю ярого свідчать, що завищені та досить часто загально прийняті норми висіву насіння можуть виявитися неефективним прийомом досягнення запланованої врожайності й економічних показників виробництва зерна ячменю. Натомість введення в технологію вирощування сучасних препаратів, що стимулюють процеси органогенезу та формування продуктивності посівів, має значно більший біологічний та економічний ефект. Використання стимуляторів, які мають гумінове походження, є цьому досить вагомим доказом та дає змогу диференціювати ці прийому для досягнення кращої ефективності.

Аналіз економічної ефективності проведених дослідів показує, що використання стимуляторів росту є досить вагомим показником підвищення рентабельності виробництва зерна ячменю. До відомих українському виробничнику препаратів,

\section{БІБЛІОГРАФІЯ}

1. Байрак Н. М. Гумісол - елемент біоорганічного землеробства / Н. М. Байрак // Пропозиція. - 2006. - №4. - C. 8-11.

2. Барабаш M. I. Використання біологічних препаратів - крок до біологічного землеробства / які можуть виявитися необхідними для удосконалення технології вирощування ячменю, слід віднести також стимулятори росту гумінового походження.

За допомогою такого прийому досягаються значно кращі умови для реалізації сортового потенціалу, а також зменшуються затрати на придбання насіннєвого матеріалу, адже у проведених дослідженнях урожайність ячменю неістотно змінювалася на варіантах без обробки, хоча економія насіннєвого матеріалу становила 11$22 \%$. Застосування ж стимулятора «4R Foliar concentrate» сприяло збільшенню врожайності та покращанню економічних показників вирощування ярого.

Висновок. Застосування сучасних стимуляторів гумінового походження дає змогу отримати стабільні прибавки врожайності зерна ячменю ярого та сприяє поліпшенню його фізичних показників якості. Для кращої реалізації потенціалу сорту та збільшення рентабельності виробництва доцільно позакоренево використовувати препарати гумінового походження, зокрема «4R Foliar concentrate», що дасть змогу зменшити затрати на придбання насіннєвого матеріалу на 11-22\%, збільшуючи в цьому разі рентабельність виробництва більше, ніж на $30 \%$.

М. Барабаш, Г. Круковський // Пропозиція. 2003. - №4. - C. 8-11.

3. Білітюк А. П. Біологізація, технологія засіб підвищення урожайності і якості зерна / А. П. Білітюк // Вісник Полтавської аграрної 
академії. - 2007. - №3. - С. 10-13.

4. Волкогон B. Мікробіологи прогнозують змінити стратегію удобрення сільгоспкультур / В. Волкогон // Пропозиція. - 2009. - №5. C. $17-21$.

5. Доспехов Б. А. Методика полевого опыта / Б. А. Доспехов. - М. : Колос, $1985 .-416$ с.

6. Каленська С. Вплив мінеральних добрив та ретардного захисту на урожайність ячменю ярого пивоварного / С. Каленська, Р. Холодченко, Б. Токар // Агробіологія. - 2015. - Вип. 1 (117). C. $56-58$.

7. Каленська С. М. Урожайність ячменю ярого залежно від рівня мінерального живлення /
С. М. Каленська, Б. Ю. Токар // Новітні технології вирощування сільськогосподарських культур : тези доповідей IV міжнар. наук.-прак. конф. 24.04.2015 p. - К., 2015. - C. 30-33.

8. Котелянець М. Г. Стан і завдання вивчення та впровадження регуляторів росту рослин / М. Г. Кателянець // Агроресурси. - К. : УДНДПТІ, 1998. - 36 с.

9. Марков I. Ярий ячмінь / I. Марков, М. Дмитришак, В. Мокрієнко // У кн. Сучасні технології АПК. Вирощування основних сільськогосподарських культур. - К. : ТОВ «Видавничий дім «Імперс- Медіа», 2011. - С. 32-55. 